\title{
Long Life, Green Burial
}

for George E. P. Box, statistician (1919-2013)

\section{Robin Chapman}

Ramshackle contraption rumbling along, a plank on wagon wheels, a shroud of unbleached linen with six straps and your grandsons and sons and friends trundling your body into the woods where the chickadees sing their courting songs and Claire reads you her poem and the frozen ground, already opened, receives you, lowered, with effort, into the earth-

not Alice's rabbit hole but a deeper one, your rainbowed hat tossed in last by a grandson and then we shovel back the dirt and walk through the cold for coffee and lime bars-another day we'll celebrate your life, how you transformed work to play and plain talk to skits and colleagues to friends and told us all models are wrong but some are useful and left us advice in Cole Porter's lyrics: experiment! As, even now, you did. 